20. Meena L.S. Survival mechanisms of pathogenic Mycobacterium tuberculosis H37Rv / / FEBS Journal, 2010, No. 277, P. 2416-2427.

21. URL: http://www.uniprot.org/ (дата обращения 05.07.17).

Видягина Олеся Сергеевна, аспирант кафедры «Болезни животных и ветеринарно-санитарная экспертиза», Саратовский государственный аграрный университет имени Н.И. Вавилова. Россия.

410012, г. Саратов, Театральная пл., 1.

Тел.: (8452) 69-25-32.

Ключевые слова: наночастицы селена; мицеллы; иммунизация; туберкулин; Мусоbacterium bovis $B C G$.

\title{
SELENIUM NANOPARTICLES AND MICELLS ARE TOOLS FOR TUBERCULOSIS PREVENTION
}

Vidyagina Olesya Sergeevna, Post-graduate Student of the chair "Animals" Diseases and Veterinarian-sanitarian Expertise", Saratov State Agrarian University named after N.I. Vavilov. Russia.

Keywords: selenium nanoparticles; micelles; immunization; Mycobacterium bovis BCG.

The adjuvant properties of micelles of nonionic detergent and $E$. coli lipids, as well as of selenium nanoparticles, were studied in the course of immunization with antigens of the diagnostic tuberculin. The formation of antibodies against PPD and Mycobacterium bovis BCG cells was studied in immunization of white mice with these constructs in comparison with the PPD immunization, using the indirect dot-immunoassay method, as well as immunoturbodimetrically. Immunization of mice with E. coli B-5 lipid or Triton X-114 micelles bearing PPD leads to the formation of antibodies against tuberculin antigens higher than for immunization with PDD itself. Immunization with all drugs, including PPD, leads to the formation of antibodies that recognize M. bovis BCG cells, but the highest levels of antibodies are observed in the blood plasma of animals receiving lipid $E$. coli B-5 or Triton X-114 micelles. The obtained results indicate the possibility of using micelles and selenium nanoparticles as an adjuvant for immunization with mycobacterial antigens.

DOI

\section{ПРОТЕОЛИТИЧЕСКИЕ ФЕРМЕНТЫ ЗЕРНА ТРИТИКАЛЕ, ПРОШЕДШЕГО УВЛАЖНЕНИЕ И ПОДСУШИВАНИЕ}

\author{
Витол Ирина Сергеевна, ВНИИЗ - филиал ФГБНУ «ФНЦ пищевых систем \\ им. В.М. Горбатова» РАН \\ ГЕРАСИНА Анна Юрьевна, ВНИИЗ - филиал ФГБНУ «ФНЦ пищевых систем \\ uм. B.М. Горбатова» РАН
}

Показано, что нейтральные протеиназы в зерновке тритикале распределены неравномерно: в зародыше сосредоточена основная часть ферментов, их активность в 5,2-6,5 раза превосходит активность в иелом зерне. Установлено, что увлажнение зерна приводит к нарастанию активности нейтральных протеиназ при влажности 30 \% она выше исходной на 60-80 \% (для иелого зерна). В зародыше активность ферментов быстро нарастает и при влажности 20 \% достигает максимума, увеличиваясь в 1,5-2,0 раза. В зерновке без зародыша активность нейтральных протеиназ при влажности 30 \% составляет 118 и $120 \%$ от исходной. Подсушивание увлажненного зерна сопровождается снижением активности нейтральных протеиназ, но остается более высокой (на 15-25\%) по сравнению с зерном исходной влажности.

Введение. Тритикале - новый вид хлебных злаков, обладающий высоким биологическим потенциалом и пищевой ценностью $[5,8,10,12,13]$. Использование тритикале как продовольственной культуры в нашей стране остается до сих пор крайне ограниченным. Однако это перспективное направление расширения сырьевой базы и ассортимента выпускаемой продукции для перерабатывающих отраслей пищевой индустрии, что подтверждается повышенным интересом к данной культуре как со стороны исследователей, так и со стороны производителей пищевых продуктов $[3,4,7,11,12]$.

Качество зернового сырья определяется не только его химическим составом, но и состоянием ферментного комплекса $[1,12]$. Известно, что повышение влажности зерна сопровождается интенсивным нарастанием активности ферментов [6]. Зерно выходит из состояния покоя, в нем получают развитие пусковые механизмы прорастания. Глубина развития этих процессов зависит прежде всего от количества поглощенной воды. Дальнейшее подсушивание зерна приводит к снижению его физиологической активности, при этом ферментные системы не возвращаются в исходное состояние. Изучение важнейших ферментных систем зерна при увлажнении и подсушивании имеет большое значение для оценки не только семенных достоинств зерна, но и технологических показателей.

Процесс увлажнения и подсушивания зерна изучали зарубежные и отечественные исследователи, в первую очередь с точки зрения его гидротермической обработки (ГТО) и дальнейшей переработки на мукомольных предприятиях [2], а также с точки зрения возможности получения различных типов тритикалевого солода для технологий бродильных производств [4]. Изучение протеолитических ферментов зерна тритикале при разных физиологических состояниях представляет не только практический интерес получения «биоактивированного» зерна. Это позволит приблизиться к пониманию роли отдельных ферментных систем в сложных пусковых механизмах прорастания. 
Цель работы - выявление закономерностей изменения активности протеолитических ферментов зерна тритикале сорта Тимирязевская- 150 урожая 2016, 2017 гг. при увлажнении и подсушивании.

Методика исследований. В качестве объекта исследования использовали зерно тритикале сорта Тимирязевская-150 урожая 2016-2017 гг., предоставленное Селекционной станцией им. П.И. Лисицына РГАУ-МСХА им. К.А. Тимирязева. Для изучения изменения ферментативной активности в зерне на разных этапах увлажнения и подсушивания опытные образцы готовили по следующей схеме: навески зерна по 10 г увлажняли до влажности 15, 18, 20, 22, 25, 28 и 30 \% путем добавления расчетного количества воды. Отволаживание проводили в течение одних суток в плотно закрытых сосудах. Подсушивание осуществляли в тонком слое на фильтровальной бумаге при комнатной температуре в течение одних суток.

Содержание водорастворимого белка определяли по методу Лоури; активность протеаз - модифицированным методом Ансона [9].

Результаты исследований. В ранее проводимых работах во Всероссийском НИИ зерна и продуктов его переработки по изучению протеолитических ферментов зерна тритикале было показано наличие трех типов протеиназ: кислые протеиназы с оптимумом рН 3,5; нейтральные $\mathrm{pH}$ 6,5; щелочные - $\mathrm{pH} 9,5$ [1]. Сорт тритикале Тимирязевская-150 характеризуется тем, что активность нейтральных в 1,3-2,0 раза выше активности кислых протеиназ (табл. 1,2 ).

Известно, что протеолитические ферменты распределены в зерне злаковых культур неравномерно. В настоящей работе на первом этапе изучали распределение нейтральных протеиназ по анатомическим частям зерновки тритикале. Следует отметить, что изучение распределения нейтральных протеиназ по анатомическим частям зерновки связано с трудностями отделения зародыша у зерна тритикале в отличие от зерна пшеницы. Тем не менее, полученные результаты позволяют су-

Таблица 1

Активность нейтральных протеиназ зерна тритикале сорта Тимирязевская-150

\begin{tabular}{|l|c|c|c|}
\hline \multicolumn{1}{|c|}{ Образец } & $\begin{array}{c}\text { Протеолити- } \\
\text { ческая } \\
\text { активность, } \Delta \mathrm{A}_{280}\end{array}$ & $\begin{array}{c}\text { Белок, } \\
\text { мг/мл }\end{array}$ & $\begin{array}{c}\text { Удельная } \\
\text { активность (УА), } \\
\Delta \mathrm{A}_{280} / \text { мг белка }\end{array}$ \\
\hline $\begin{array}{l}\text { Тимирязевская-150, } \\
\text { урожай 2016 г. }\end{array}$ & 0,120 & 0,40 & 0,30 \\
\hline $\begin{array}{l}\text { Тимирязевская-150, } \\
\text { урожай 2017 г. }\end{array}$ & 0,220 & 0,35 & 0,62 \\
\hline
\end{tabular}

Таблица 2

Активность кислых протеиназ зерна тритикале сорта Тимирязевская-150

\begin{tabular}{|l|c|c|c|}
\hline \multicolumn{1}{|c|}{ Образец } & $\begin{array}{c}\text { Протеолити- } \\
\text { ческая } \\
\text { активность, } \Delta \mathrm{A}_{280}\end{array}$ & $\begin{array}{c}\text { Белок, } \\
\text { мг/мл }\end{array}$ & $\begin{array}{c}\text { Удельная } \\
\text { активность, } \\
\mathrm{A}_{280} / \text { мг белка }\end{array}$ \\
\hline $\begin{array}{l}\text { Тимирязевская-150, } \\
\text { урожай 2016 г. }\end{array}$ & 0,090 & 0,40 & 0,23 \\
\hline $\begin{array}{l}\text { Тимирязевская-150, } \\
\text { урожай 2017 г. }\end{array}$ & 0,110 & 0,35 & 0,31 \\
\hline
\end{tabular}

дить о соотношении нейтральных протеиназ в зародыше и оставшейся части зерновки: в зародыше сосредоточена основная часть ферментов - их активность в 5,2-6,5 раза превосходит активность в целом зерне (табл. 3).

Таблица 3

Распределение нейтральных протеиназ по анатомическим частям зерновки

\begin{tabular}{|c|c|c|c|}
\hline \multirow{2}{*}{ Образец } & \multirow{2}{*}{$\begin{array}{c}\text { Часть } \\
\text { зерновки }\end{array}$} & \multicolumn{2}{|c|}{$\begin{array}{c}\text { Активность } \\
\text { нейтральных протеиназ }\end{array}$} \\
\hline & & $\begin{array}{c}\text { УА, } \\
\Delta \mathrm{A}_{280} / \mathrm{Mг} \text { белка }\end{array}$ & $\begin{array}{c}\text { доля от целого } \\
\text { зерна, \% }\end{array}$ \\
\hline $\begin{array}{l}\text { Тимирязев- } \\
\text { ская-150, } \\
\text { урожай } 2016 \text { г. }\end{array}$ & $\begin{array}{l}\text { Целое зерно } \\
\text { Зародыш } \\
\text { Зерновка } \\
\text { без зародыша }\end{array}$ & $\begin{array}{l}0,30 \\
1,56 \\
0,21\end{array}$ & $\begin{array}{l}100 \\
520 \\
70 \\
\end{array}$ \\
\hline $\begin{array}{l}\text { Тимирязев- } \\
\text { ская-150, } \\
\text { урожай } 2017 \text { г. }\end{array}$ & $\begin{array}{l}\text { Целое зерно } \\
\text { Зародыш } \\
\text { Зерновка } \\
\text { без зародыша }\end{array}$ & $\begin{array}{l}0,62 \\
4,03 \\
0,49\end{array}$ & $\begin{array}{l}100 \\
650 \\
79\end{array}$ \\
\hline
\end{tabular}

Таким образом, нейтральные протеиназы в зерновке тритикале распределены неравномерно. В зародыше сосредоточена основная часть ферментов, извлекаемая 0,35\%-м раствором соды [1].

Учитывая факт физиологических различий тканей эндосперма и зародыша, разную направленность процессов, происходящих в них при прорастании, а также локализацию ферментов, на втором этапе работы изучали изменение активности нейтральных протеиназ при увлажнении и подсушивании для целого зерна, зародыша и зерновки без зародыша (рис. 1-3).

Для целого зерна характерно последовательное нарастание активности нейтральных протеиназ, при влажности $30 \%$ она выше исходной на 60-80 \% для зерна тритикале сорта Тимирязевская-150 урожая 2016 и 2017 гг. соответственно.

В зародыше активность ферментов быстро нарастает и при влажности 20 \% достигает максимума, увеличиваясь в 1,5-2,0 раза. Дальнейшее увлажнение приводит к снижению активности нейтральных протеаз в зародыше.

В зерновке без зародыша активность нейтральных протеиназ медленно нарастает в период увлажнения до влажности 20 \%, после которой наблюдается более интенсивный рост протеолитической активности. При влажности 30 \% протеолитическая активность составляет 118 и $120 \%$ соответственно для зерна тритикале урожая 2016 и 2017 гг.

Следует отметить, что снижение активности протеиназ в зародыше точно соответствует заметному увеличению активности в зерновке без зародыша. Это происходит при влажности $20 \%$. Вероятно, взаимосвязь этих процессов заключается в том, что зародыш в начальный период увлажнения активно синтезирует протеазы de novo, а при достижении определенной влажности секретирует их в клетки эндосперма, запуская тем самым мобилизацию запасных белков в соответствии с ростовыми процессами.

Подсушивание увлажненного зерна сопровождается снижением активности нейтральных про- 


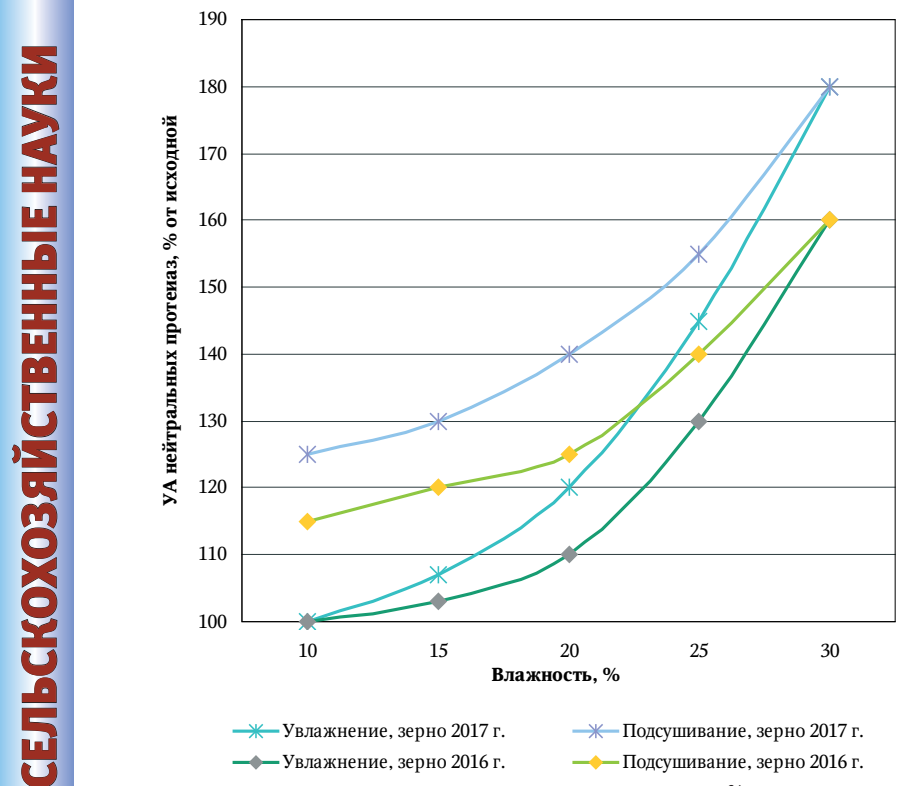

Рис.1. Изменение активности нейтральных протеиназ целой зерновки тритикале сорта Тимирязевская-150 при увлажнении и подсушивании

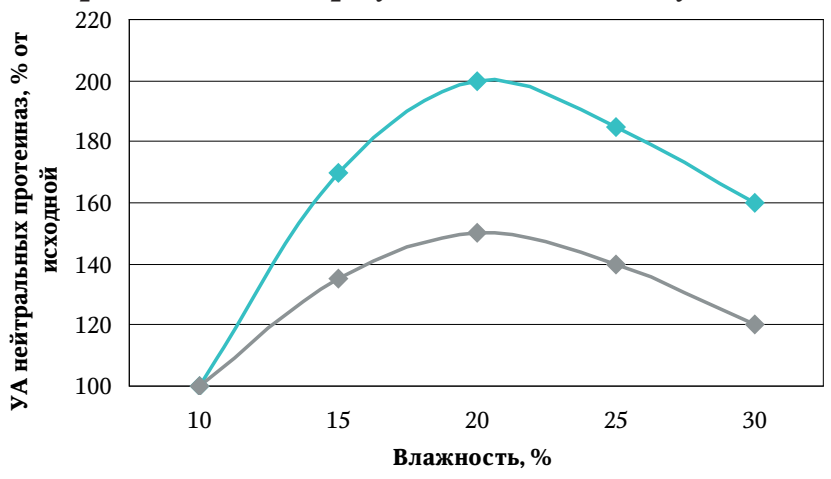

Рис. 2. Изменение активности нейтральных протеиназ зародыша зерна тритикале сорта Тимирязевская-150 при увлажнении

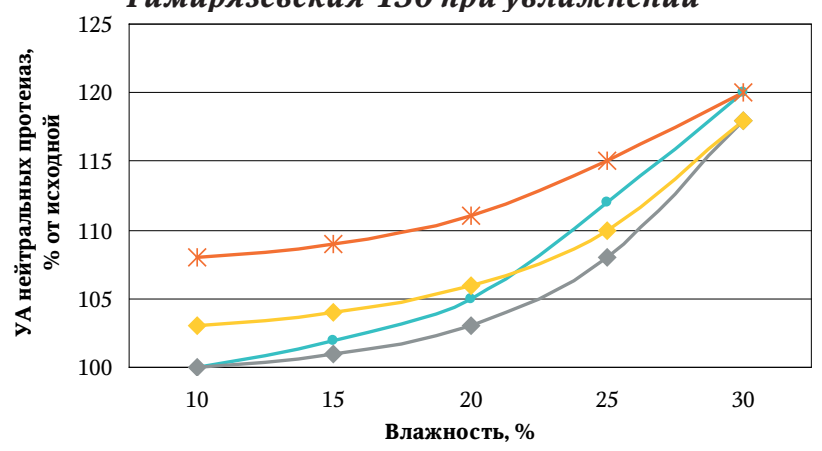

—-Увлажнение, зерно 2017 г. $\quad$ - — Подсушивание, зерно 2017 г. $\multimap$ Увлажнение, зерно 2016 г. $\longrightarrow$ Подсушивание, зерно 2016 г.

Рис. 3. Изменение активности нейтральных протеиназ зерновки без зародыша тритикале сорта Тимирязевская-150 при увлажнении и подсущивании

теиназ для всех исследуемых образцов, но остается более высокой по сравнению с зерном исходной влажности. У образцов целого зерна тритикале после увлажнения и подсушивания активность нейтральных протеиназ выше исходной на 15 \% (урожай 2016 г.) и на 25 \% (урожай 2017 г.), см. рис. 1. Активность нейтральных протеаз, извлекаемых из зародыша зерна, после увлажнения и подсушивания на 35 \% выше, чем у зародыша исходного зерна.

В зерновке без зародыша также происходит снижение протеолитической активности, при этом разница между активностью нейтральных протеиназ исходного зерна и прошедшего увлаж- нение и подсушивание минимальная. У этих образцов она выше исходной на 3-8 \% (см. рис. 3).

Таким образом, нейтральные протеиназы зерна относятся к ферментам, участвующим в формировании пусковых механизмов прорастания: рост их активности начинается с поглощением семенем первых порций воды, причем первостепенная роль в этом принадлежит протеиназам зародыша. После подсушивания их активность значительно превосходит исходную для зерна той же влажности.

Заключение. Зерно тритикале, прошедшее увлажнение и подсушивание, характеризуется более высокой активностью ферментных систем. Активность нейтральных протеиназ в зерне, прошедшем увлажнение и подсушивание, на $15-25 \%$ превышает их активность в исходном зерне той же влажности, в зародыше - на $35 \%$.

Полученные данные позволят направленно воздействовать на биологические системы зерна. Это важно для получения зерна, обладающего определенными технологическими и биохимическими показателями. Активированное таким образом зерно тритикале может служить сырьем для получения продуктов (разные типы муки и крупы) с заданными свойствами.

\section{СПИСОК ЛИТЕРАТУРЫ}

1. Белково-протеиназный комплекс зерна тритикале / И.С. Витол [и др.] // Хранение и переработка сельхозсырья. - 2015. - № 8. - С. 36-39.

2. Кандроков Р.Х., Стариченков А.А., Штейнберг Т.С. Влияние ГТО на выход и качество тритикалевой муки // Хлебопродукты. - 2015. - № 1. - С. 64-65.

3. Касынкина О.М., Орлова Н.С., Каневская И.Ю. Качество пшеничного хлеба, выпеченного с добавлением муки из тритикале // Аграрный научный журнал. - 2015. - № 12. - С. 18-20.

4. Кобелев К.В., Гернет М.В., Грибкова И.Н. Свойства тритикале и перспективы ее использования в бродильных напитках // Хранение и переработка сельхозсырья. - 2013. - № 5. - С. 51-53.

5. Кобелев К.В., Гернет М.В., Хурушудян С.А. Тритикале - перспективная зерновая культура // Пиво и напитки. - 2016. - № 3. - С. 26-29.

6. Козьмина Н.П. Биохимия зерна и продуктов его переработки. - М.: Колос, 1976. - 375 с.

7. Леонова С.А., Пусенкова Л.И., Погонеи Е.В. Оценка хлебопекарных свойств перспективных селекционных видов тритикале // Хлебопродукты. - 2013. № 6. - C. $40-41$.

8. Оценка качества зерна тритикале/ Е.П. Мелешкина [и др.] // Хлебопродукты. - 2015. - № 2. - С. 48-49.

9. Пищевая химия. Лабораторный практикум / А.П. Нечаев [и др.]. - СПб.: ГИОРД, 2006. - 304 с.

10. Рубеи В.С., Игонин В.Н., Пыльнев В.В. Селекция озимой тритикале в РГАУ-МСХА им. К.А. Тимирязева: история, особенности, достижения // Известия TCXA. - 2014. - № 1. - C. 115-124.

11. Технологические и биохимические показатели в оценке качества зерна тритикале сорта Тимирязевская 150 / И.С. Витол [и др.] // Вестник Алтайского государственного университета. - 2017. - № 8 (154). - С. 43-48.

12. Технологические и биохимические показатели как составляющие качества муки тритикале / Г.Н. Панкратов [и др.] // Контроль качества продукции. -2017 . - № 2. - С. 38-44.

13. Thomas T.M. Triticale - anewcereal // Farm Food Research, 1984, Vol. 15, No. 5, P. 191. 
Витол Ирина Сергеевна, канд. биол. наук, старший научный сотрудник, ВНИИЗ - филиал ФГБНУ «ФНЦ пищевых систем им. В.М. Горбатова» РАН. Россия.

Герасина Анна Юрьевна, аспирант, младший научный сотрудник, ВНИИЗ - филиал ФГБНУ «ФНЦ пищевых систем им. В.М. Горбатова» РАН. Россия.
127434, г. Москва, Дмитровское шоссе, д. 11.

Тел.: 89267090207; e-mail: vitolis@yandex.ru.

Ключевые слова: тритикале; зерно; биопотенииал; протеолитические ферменты; увлажнение; подсушивание.

\title{
PROTEOLYTIC ENZYMES OF GRAIN TRITYCLE AFTER HUMIDIFICATION AND DRYING
}

Vitol Irina Sergeevna, Candidate of Biological Sciences, Senior Researcher, All-Russian Scientific Research Institute of Grain and Products of Its Processing - branch «V.M. Gorbatov Federal Research Center for Food Systems» of the Russian Academy of Sciences. Russia.

Gerasina Anna Yuryevna, Younger Researcher, AllRussian Scientific Research Institute of Grain and Products of Its Processing - branch «V.M. Gorbatov Federal Research Center for Food Systems» of the Russian Academy of Sciences. Russia.

Keywords: triticale; corn; biopotential; proteolytic enzymes; humidification; drying.
It has been shown that neutral proteinases in the triticale grain are distributed unevenly: the activity of enzymes are concentrated in the embryo - their activity is 5.2-6.5 times higher than that of whole grain. It has been established that moistening of the grain leads to an increase in the activity of neutral proteinases - at a content wetness of $30 \%$ it is higher than the initial protein by $60-80 \%$ (for whole grains). In the embryo, the activity of the enzymes rapidly increases and, with a wetness content of $20 \%$, reaches a maximum, increasing 1.5-2.0 times. In a seed without an embryo, the activity of neutral proteinases at a humidity of $30 \%$ is $118 \%$ and $120 \%$ of the initial one. Drying of moistened grain is accompanied by a decrease in the activity of neutral proteinases, but remains higher (by 15-25\%) compared to grain with the initial moisture content.

DOI

УдК 634.324: 631.52

\section{КРИТЕРИИ ПОДБОРА КОМБИНАЦИЙ СКРЕЩИВАНИЯ ДЛЯ СОЗДАНИЯ ГИБРИДНОГО ФОНДА МАНДАРИНА (CITRUS RETICULATA BLAN. VAR. UNCHIU TAN.)}

\author{
кУЛЯН Раиса Васильевна, Всероссийский научно-исследовательский институт иветоводства \\ и субтропических культур
}

В селекиионной практике с иитрусовыми культурами для получения гибридных семян учитываются следующие основные принципы: признаковый, географический. Признаковый принцип (Citrus reticulata Blan. var. unchiu Tan.) позволяет основываться на использовании источников селекционно-значимых признаков урожайности, низкорослости, биотической и абиотической устойчивости, комплексном содержании компонентов биохимического состава; оценка исходных форм проводится по фенотипу. Географический принцип основан на применении межродовой и межвидовой гибридизации. Использование диких, полудиких и культурных сородичей ичтрусовых позволяет получать гибриды с больиим спектром изменчивости по важным признакам (раннеспелость, скороплодность, крупноплодность). Проанализиров 47 комбинаций скрещивания, выделена 21 перспективная для создания гибридного фонда мандарина, где материнские формы 'КошапоWase', 'Miyagawa Wase', 'Юбилейный' передают своему потомству низкорослость, раннеспелость, урожайность, качество плодов. Сородичи и гибридные виды иитрусовых С. $\times$ tangelo, C. $\times$ clementina, C. $\times$ leiocarpa, C. $\times$ insitorum, P. trifoliata, гибрид 3252 передают зимостойкость, крупноплодность. Самъми результативнъми комбинациями по въходу зимостойких сеянщев являются скрещивания 'Miyagawa Wase' $\times$ P. trifoliata, 'Kowano-Wase' $\times$ P. trifoliata и 'Kowano-Wase' $\times$ C. $\times$ insitorum. Наибольший выход низкорослых сеянцев отмечен в комбинациях с участием в качестве опылителя С. leiосагра. В комбинациях 'Юбилейный' $\times$ C. $\times$ insitoruт, 'Юбилейный' × гибрид 3252, 'Miyagawa Wase' $\times$ C. $\times$ insitorum выделено наибольщее количество раннеспелых форм. Крупноплодность передают потомству отиовские формы C. $\times$ insitorum, C. sinensis 'Valencia'.

Введение. Цитрусовые широко культивируют во многих субтропических и тропических областях земного шара, в странах Средиземноморья (Испания, Италия, Марокко и др.), на юге США (Калифорния, Флорида), в Бразилии, Аргентине, Японии, Китае, Индии, Пакистане, Индокитае, Австралии и ЮАР. Самыми распространенными цитрусовыми культурами являются апельсин, мандарин и лимон с их многочисленными сортами. В России цитрусовые выращивают в субтропической зоне Черноморского побережья, которая является самым северным в мире районом их возделывания. Промышленное значение здесь имеет мандарин [5].

Мандарин (Citrus reticulata Blan. var. unchiu Tan.) по вкусовым качествам превосходит все другие цитрусовые. Поэтому в последние годы наблюдается неуклонный рост производства мандаринов, в связи с чем именно в этой группе цитрусовых постоянно появляется наибольшее количество новых сортов и гибридных видов. Скрещивание C. reticulata c разными генотипами является основным методом получения новых сочетаний признаков.

При гибридизации, особенно отдаленной, можно получать новые формы, не похожие на исходные, и объединять в потомстве свойства и признаки родительских форм, иногда исправлять отдельные недостатки сорта. Подбор родительских пар, а также методы дальнейшей работы с гибридами, полученными в предыдущие годы, имеют большое значение и часто определяют успех селекционной 